\title{
Deteksi Molekuler Burkholderia glumae, Penyebab Penyakit Hawar Malai Padi
}

\section{Molecular Detection of Burkholderia glumae, A Causal Agent of Bacterial Panicle Blight Disease}

\author{
Methy Handiyanti ${ }^{1)^{*}}$, Siti Subandiyah ${ }^{2)}$, \& Tri Joko ${ }^{2)}$ \\ ${ }^{1)}$ Balai Besar Uji Standar Karantina Pertanian, Badan Karantina Pertanian \\ Jln. Pemuda No. 64 Kav. 16-17, Rawamangun, Jakarta Timur, 13320 \\ ${ }^{2}$ Departemen Hama dan Penyakit Tumbuhan, Fakultas Pertanian, Universitas Gadjah Mada \\ Jln. Flora No. 1, Bulaksumur, Sleman, Yogyakarta 55281 \\ *Penulis untuk korespondensi.E-mail: methy.handi@gmail.com
}

Diterima 13 November 2017; diterima untuk diterbitkan 19 Maret 2018

\begin{abstract}
The presence of bacterial panicle blight disease caused by Burkholderia glumae have been reported to infect rice plants in Indonesia. There have been no reports of yield losses due to B. glumae infection, but this pathogen is seed-borne so that it can increase the spreading potential to other areas. This study aims to determine the spread of the disease area of bacterial panicle blight in Java and to detect B. glumae based on ITS region of 16-23S rDNA. Methods for this research include surveys and random sampling of rice seeds directly from farmers and the Food Crop and Horticulture Center, Agriculture Office of Yogyakarta. The bacteria were isolated using S-PG selective medium, then DNA extraction was performed and amplified using a pair of primers BGF 5'-ACACGGAACACCTGGGTA-3' and BGR 5'TCGCTCTCC CGAAGAGAT-3'. 101 isolates were obtained from 21 seed samples consisting of 11 rice varieties from nine regions in Java that has different morphological characteristics. The eight isolates were detected as B. glumae by using ITS primers, i.e., isolates ChgCM.4, IRP.3, IRP.6b, InSB.1 a, InSB.2a, InSB.3a, InSB.5a, and InSB.6a. The eight isolates were isolated from seed samples of Cirebon, Purworejo and Banyuwangi. This study shows that bacterial panicle blight disease has found in several rice varieties and locations in Java, and the ITS primer can be used for early detection of $\mathrm{B}$. glumae in rice seed samples.
\end{abstract}

Keywords: bacterial panicle blight, Burkholderia glumae, rice seed

\section{INTISARI}

Penyakit hawar malai yang disebabkan oleh bakteri patogen Burkholderia glumae mulai banyak dilaporkan menginfeksi tanaman padi di Indonesia. Belum ada laporan mengenai kerugian akibat infeksi B. glumae di Indonesia, namun sifatnya yang tular benih dapat meningkatkan potensi menyebar ke wilayah lain. Penelitian ini bertujuan untuk mengetahui wilayah sebar penyakit hawar malai di Jawa dan mendeteksi secara molekuler berdasarkan urutan basa gen 16-23S rDNA internal transcribed spacer (ITS). Metode yang dilakukan meliputi survei dan pengambilan sampel biji padi secara acak langsung dari petani dan UPT Balai Pengembangan Perbenihan Tanaman Pangan dan Hortikultura, Dinas Pertanian Yogyakarta. Sampel biji padi diisolasi menggunakan media selektif S-PG, kemudian dilakukan ekstraksi DNA, dan diamplifikasi menggunakan primer BGF 5' - ACACGGAACACCTGGGTA-3' dan BGR 5'-TCGCTCTCC CGAAGAGAT-3'. Hasil survei di lapangan diperoleh 21 sampel biji yang terdiri dari 11 varietas padi dari sembilan wilayah di Jawa. Hasil isolasi diperoleh 101 isolat dan masing-masing isolat tersebut memiliki karakteristik morfologi yang berbeda. Delapan isolat dari total isolat yang diuji terdeteksi $B$. glumae menggunakan primer ITS, yaitu isolat ChgCM.4, IRP.3, IRP.6b, InSB.1a, InSB.2a, InSB.3a, InSB.5a, dan InSB.6a. Kedelapan isolat tersebut merupakan hasil isolasi sampel biji dari wilayah Cirebon, Purworejo, dan Banyuwangi. Hasil penelitian menunjukkan bahwa penyakit hawar malai bakteri sudah terdeteksi pada varietas padi di beberapa lokasi wilayah Jawa, dan penggunaan primer ITS dapat digunakan untuk deteksi dini B. glumae pada sampel biji padi secara molekuler.

Kata kunci: biji padi, Burkholderia glumae, hawar malai padi 


\section{PENDAHULUAN}

Jawa merupakan salah satu wilayah pertanaman dan penghasil padi terbesar di Indonesia (Anonim, 2017). Produktivitas padi di Jawa dipengaruhi oleh berbagai faktor, di antaranya penggunaan bibit, pengolahan tanah, pengelolaan tanaman serta adanya infeksi patogen penyebab penyakit tumbuhan. Beberapa penyakit penting pada tanaman padi di Indonesia di antaranya blas, hawar daun bakteri, hawar pelepah, serta tungro. Selain penyakit tersebut saat ini mulai banyak laporan tentang penyakit hawar malai yang disebabkan oleh Burkholderia glumae. Penyakit ini pertama kali dilaporkan keberadaannya di Jepang tahun 1955, dan diketahui dapat menyebabkan gejala busuk bulir dan hawar pada bibit padi (Tsushima et al., 1986). Menurut Wamishe (2014), gejala penyakit ini lebih sering ditemukan pada bulir padi, sehingga lebih dikenal dengan nama busuk bulir (grain rot) di beberapa wilayah Asia. Hawar malai diketahui menjadi salah satu penyakit penting pada pertanaman padi di Amerika, Korea, dan Jepang (Jeong et al., 2003; Nandakumar et al., 2009, Zhou-qi et al., 2016).

Gejala infeksi $B$. glumae dapat muncul pada bagian pelepah berupa bercak panjang keabuan dengan bagian tepi berwarna cokelat kemerahan. Karakteristik lainnya yaitu malai tumbuh ke atas dan berwarna kekuningan dengan bagian pangkal bunga berwarna gelap serta terdapat garis cokelat kemerahan yang melintang di bagian tengah. Pada tingkat infeksi yang tinggi, proses pengisian bulir dapat terganggu. Hal ini menyebabkan malai tumbuh tegak, karena bulir tidak terisi (Nandakumar et al., 2009).

Infestasi B. glumae pada pertanaman padi di Indonesia masih belum sebanyak penyakit hawar daun bakteri oleh Xanthomonas oryzae pv. oryzae (Suparyono et al., 2004) dan penyakit blas oleh Pyricularia oryzae (Santoso \& Nasution, 2017). Kerugian yang disebabkan oleh penyakit hawar malai di Indonesia belum pernah dilaporkan sebelumnya. Namun melihat dari ekologinya, kondisi iklim yang panas dan kering serta curah hujan yang cukup tinggi di Indonesia saat ini sangat sesuai untuk perkembangan penyakit hawar malai. Hal ini tentu akan berpengaruh terhadap peningkatan intensitas serta keparahan penyakit (Joko, 2017). Bakteri patogen ini dapat terbawa benih (Takeuchi et al., 1997), sehingga potensi menyebar ke wilayah lain menjadi lebih besar dan dikhawatirkan akan muncul outbreak di masa yang akan datang (Windari et al., 2015).
Penelitian ini bertujuan untuk mengetahui daerah sebar penyakit hawar malai di wilayah Jawa dan cara mendeteksi infeksi oleh $B$. glumae pada biji padi secara molekuler.

\section{BAHAN DAN METODE}

\section{Survei dan Pengambilan Sampel Biji Padi di Berbagai Lokasi}

Penelitian yang dilakukan meliputi survei tanaman dan pengambilan sampel biji padi. Dari setiap kabupaten kemudian dipilih tiga lokasi pertanaman menggunakan metode purposive random sampling (Joko et al., 2011a; Mahfut et al., 2016; Ismiyatuningsih et al., 2016). Survei tanaman padi dilakukan di wilayah Purwakarta (Jawa Barat), Bantul dan Kulon Progo (Yogyakarta), serta Purworejo (Jawa Tengah). Pengambilan sampel biji padi diambil dari beberapa wilayah di Jawa Barat, Jawa Tengah, Jawa Timur dan Yogyakarta. Biji padi secara acak diambil langsung dari petani dan UPT Balai Pengembangan Perbenihan Tanaman Pangan dan Hortikultura, Dinas Pertanian Yogyakarta. Data lokasi pengambilan sampel dan varietas padi dapat dilihat pada Tabel 1. Sampel biji padi diambil dari petani dan kantor dinas terkait, yang memiliki gejala berupa bercak cokelat di bagian permukaan kulitnya. Sampel biji diambil secara acak kemudian dicatat varietas serta nama daerah pengambilan sampel.

\section{Isolasi Burkholderia glumae dari Biji Padi}

Biji padi yang menunjukkan gejala penyakit digerus dan ditambahkan buffer salin $(\mathrm{NaCl} 8,5 \mathrm{~g}$, akuades steril 1). Suspensi tersebut kemudian ditumbuhkan pada media selektif S-PG $\left(1,3 \mathrm{~g} \mathrm{KH}_{2} \mathrm{PO}_{4}\right.$,

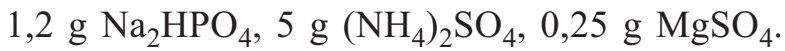
$7 \mathrm{H}_{2} \mathrm{O}, 24 \mathrm{mg} \mathrm{Na} \mathrm{MoO}_{4} \cdot 2 \mathrm{H}_{2} \mathrm{O}, 10 \mathrm{mg}$ EDTA-Fe, $10 \mu \mathrm{g}$ L-cystine, $15 \mathrm{~g}$ agar, $10 \mathrm{~g}$ D-sorbitol, $50 \mathrm{mg}$ pheneticilin potassium, $10 \mathrm{mg}$ ampicilin sodium, $10 \mathrm{mg}$ cetrimide, $1 \mathrm{mg}$ methyl violet dan $20 \mathrm{mg}$ phenol red) (Tsushima, 1996), dan diinkubasi pada suhu $37^{\circ} \mathrm{C}$ selama 5-7 hari. Koloni yang memiliki karakteristik seperti tipe A (koloni bulat, cembung, dan berwarna cokelat kemerahan) atau B (opalescens dengan bagian tengah berwarna ungu atau ungu kemerahan), diambil dan dilakukan pemurnian pada media agar King's B (protease peptone $20 \mathrm{~g}$, gliserol $15 \mathrm{ml}, \mathrm{K}_{2} \mathrm{HPO}_{4} \cdot \mathrm{H}_{2} \mathrm{O} 1,5 \mathrm{mg}, \mathrm{MgSO}_{4} \cdot 7 \mathrm{H}_{2} \mathrm{O} 1,5 \mathrm{~g}$, agar $15 \mathrm{~g}$, akuades $11 \mathrm{~L}$ ) dan LB (tryptone $10 \mathrm{~g}$, $\mathrm{NaCl} 10 \mathrm{~g}$, yeast extract $5 \mathrm{~g}$, agar $20 \mathrm{~g}$, akuades $1 \mathrm{~L}$ ), kemudian diinkubasikan pada suhu $37^{\circ} \mathrm{C}$ selama 
Tabel 1. Varietas padi dan lokasi pengambilan sampel biji padi yang digunakan untuk isolasi Burkholderia glumae

\begin{tabular}{ll}
\hline Varietas padi & Lokasi pengambilan sampel biji padi \\
\hline Ciherang, IR64, Mekongga & Cirebon, Jawa Barat \\
Cibogo & Purwakarta, Jawa Barat \\
Inpari 23, IR64, Memberamo & Klaten, Jawa Tengah \\
Ciherang, IR64 & Purworejo, Jawa Tengah \\
Pepe & Bantul, Yogyakarta \\
Ciherang & Kulon Progo, Yogyakarta \\
Cibogo, Inpari 4, Inpari Sidenuk, IR64, Situ Bagendit & Banyuwangi, Jawa Timur \\
Ciherang, Logawa, Situ Bagendit & Jember, Jawa Timur \\
Ciherang & Lumajang, Jawa Timur \\
Sembada & China (Impor) \\
\hline
\end{tabular}

24-48 jam. Koloni yang bersifat diffusible nonfluorescent yang menunjukkan koloni B. glumae (Joko et al., 2000; Schaad et al., 2001) selanjutnya dilakukan pengujian secara molekuler dengan teknik polymerase chain reaction (PCR).

\section{Identifikasi B. glumae Menggunakan Primer Berdasarkan Daerah ITS}

Total genom bakteri diisolasi dengan teknik minipreparation DNA isolation (Joko et al., 2011b) dan menggunakan isolat bakteri yang telah ditumbuhkan pada media LB berumur 24 jam. DNA hasil isolasi kemudian diamplifikasi dengan PCR menggunakan primer 16-23S ribosomal DNA (rDNA) ITS (BGF 5'-ACACGGAACACCTGGGTA-3', dan BGR 5'-TCGCTCTCCCGAAGAGAT-3') dengan produk amplifikasi 400 pasang basa (Nandakumar et al., 2009). Komposisi PCR dengan reaksi $25 \mu 1$ yang terdiri dari 12,5 $\mu 1$ mastermix PCR (BIOLINE MyTaq HS Red Mix), ditambah dengan $1 \mu \mathrm{l}$ masingmasing primer, 9,5 $\mu 1$ nuclease free water, dan $1 \mu 1$ sampel. Proses amplifikasi menggunakan mesin thermal cycler Esco Health Care. Program PCR yang digunakan sebagai berikut: denaturasi awal pada $94^{\circ} \mathrm{C}$ selama 10 menit, diikuti 30 siklus yang terdiri dari $94^{\circ} \mathrm{C}$ selama 30 detik, $52^{\circ} \mathrm{C}$ selama 20 detik, dan $72^{\circ} \mathrm{C}$ selama 30 detik. Kemudian dilanjutkan dengan pemanjangan akhir pada suhu $72^{\circ} \mathrm{C}$ selama 10 menit (Joko et al. 2007; Mahfut et al., 2016). Visualisasi hasil PCR dilakukan dengan memasukkan $8 \mu 1$ sampel ke dalam lubang 1,5\% gel agarosa dan dielektroforesis pada voltase $70 \mathrm{~V}$ selama 55 menit. Pita DNA terlihat pada gel agarosa setelah diberi pewarnaan dengan perendaman selama 20 menit dalam larutan ethidium bromide (Joko et al., 2012; 2014).

\section{HASIL DAN PEMBAHASAN}

\section{Survei dan Pengambilan Sampel Biji Padi di Berbagai Lokasi}

Hasil survei di lapangan diperoleh 21 sampel biji yang terdiri dari 11 varietas padi. Masing-masing sampel diperiksa gejala yang terlihat pada bagian permukaan luar biji. Gejala bercak cokelat pada sampel biji IR64 asal Purworejo (IRP) dan Ciherang asal Cirebon (ChgCM) dapat jelas terlihat pada permukaan kulit biji (Gambar 1). Bercak cokelat ditemukan pada pangkal bulir yang semakin meluas ke bagian tengah biji. Bercak cokelat tidak terlalu jelas terlihat pada sampel Inpari Sidenuk asal Banyuwangi (InSB). Hal ini dapat disebabkan oleh adanya perbedaan tingkat keparahan penyakit dari masingmasing sampel. Selain itu tingkat virulensi dari strain B. glumae yang menginfeksi juga dapat menghasilkan perbedaan kemunculan gejala pada tanaman inang (Nandakumar et al., 2009).

Penyakit hawar malai atau busuk bulir menjadi salah satu penyakit baru (emerging disease) di dunia. Penyakit ini menyebabkan busuk pada benih, perubahan warna cokelat pada pelepah daun. Bakteri ini juga diketahui dapat menginfeksi dan menyebabkan layu pada beberapa tanaman seperti tomat, perila, cabai dan terong. Berbeda dengan bakteri busuk lunak yang memproduksi enzim ekstraselular sebagai faktor patogenisitasnya (Joko et al., 2018), B. glumae diketahui menghasilkan toksin yang diduga sebagai salah satu faktor virulensi (Jeong et al., 20013). Dari beberapa penelitian diketahui bahwa B. glumae menghasilkan tingkat infeksi yang tinggi pada tahap pertumbuhan akhir, yaitu pada fase pembungaan dan pembentukan bulir. Bakteri ini dapat ditemukan pada bagian pelepah daun, namun tidak terdeteksi pada permukaan daun. Populasi bakteri 


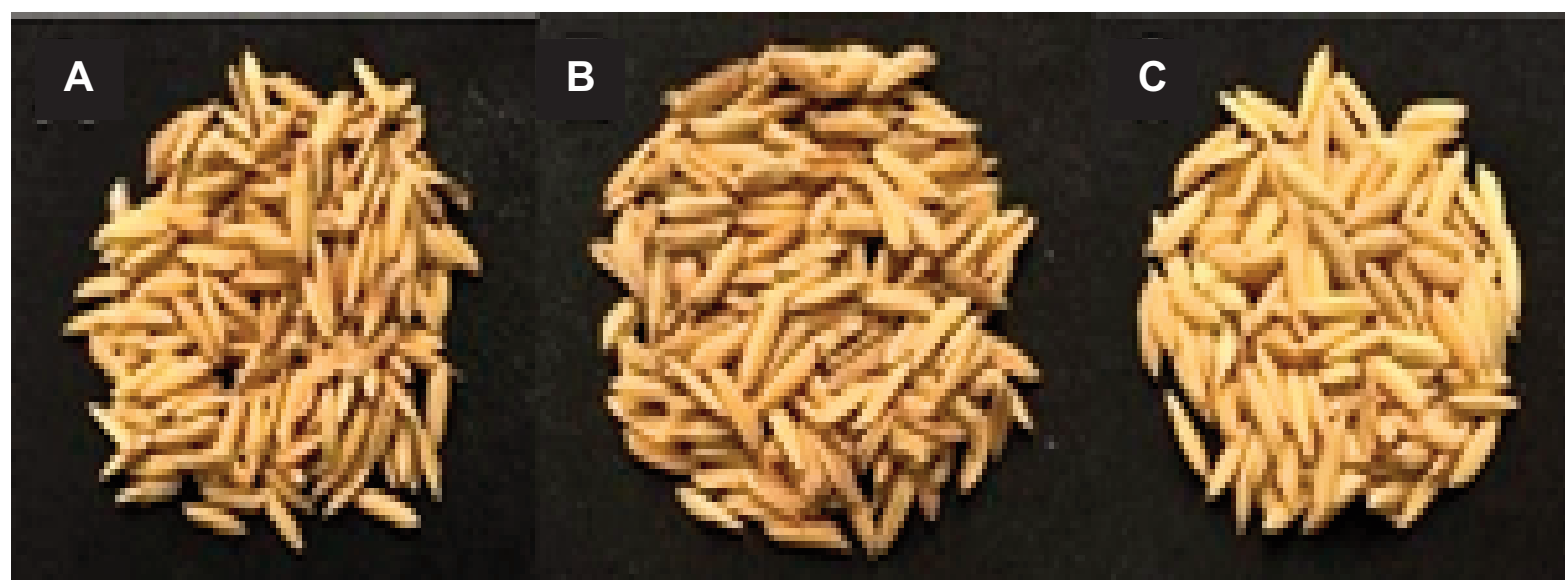

Gambar 1. Sampel biji padi varietas A) IR64, Purworejo (IRP), B) Ciherang, Cirebon (ChgCM), dan C) Inpari Sidenuk, Banyuwangi (InSB); biji padi yang terinfeksi Burkholderia glumae memiliki ciri bercak cokelat di bagian permukaan kulitnya; bercak cokelat dapat ditemukan pada bagian uji biji atau melintang di bagian tengah

pada pelepah daun bervariasi mulai dari jumlah yang sedikit hingga mencapai $10^{6} \mathrm{CFU} / \mathrm{g}$. Populasi tersebut semakin tinggi pada bagian spikelet tanaman. B. glumae mengkolonisasi pada permukaan pangkal lodicula yang merupakan dua daun mahkota yang telah berubah bentuk dan permukaan dalam lemma (Tsushima, 1996).

Penelitian yang dilakukan oleh Cottyn et al. (1996) terhadap benih padi yang diberi perlakuan inokulum B. glumae, menunjukkan bahwa terjadi penurunan daya kecambah pada benih yang telah diberi perlakuan tersebut. Infeksi $B$. glumae dapat menyebabkan busuk pada masa perkecambahan. Selain itu, bibit padi yang terinfeksi juga akan tumbuh lebih kecil dan terdapat bercak busuk berwarna cokelat pada bagian pelepah. Daun mengalami perubahan morfologi menjadi keriting, melengkung dan memutih pada 1 hingga 2 minggu setelah inokulasi.

\section{Karakteristik B. glumae dari Biji Padi}

Isolat-isolat yang ditumbuhkan pada media selektif S-PG berwarna cokelat kemerahan dan ungu kemerahan. Sebanyak 8 isolat yang memiliki karakteristik morfologi sesuai dengan $B$. glumae diperoleh dari hasil isolasi benih. Isolat tersebut berasal dari beberapa wilayah di Jawa yaitu Cirebon, Purworejo dan Banyuwangi. Dari keseluruhan isolat yang diperoleh, sebanyak lima isolat memiliki tipe koloni A yaitu berwarnae coklat kemerahan dan tiga isolat lainnya termasuk dalam tipe B yaitu opalescens berwarna ungu kemerahan. Kedua tipe ini tidak membedakan virulensi karakter isolatnya, namun hanya merupakan variasi fenotip dari masing-masing strain (Tsushima et al., 1986). Isolat yang tumbuh dengan ciri morfologi tipe A yaitu InSB.1a, InSB.2a, InSB.6a, IRP.6b dan ChgCM.4, sedangkan isolat tipe B yaitu InSB.3a, InSB.5a, dan IRP.3 (Gambar 2).

Media selektif S-PG ini dikembangkan oleh Tsushima (1996), untuk mendeteksi dan mengamati tipe koloni yang tumbuh, yaitu tipe A dan B. Hasil identifikasi terhadap isolat $B$. glumae yang diisolasi dari beberapa wilayah di Jepang menunjukkan bahwa isolat dari wilayah selatan memiliki karakteristik koloni tipe A, sedangkan koloni tipe B dapat ditemukan hampir di seluruh wilayah Jepang.

Pada proses pemurnian dan peremajaan, isolat bakteri dengan ciri morfologi yang sesuai ditumbuhkan pada media agar LB dan King's B, dan diinkubasi pada suhu $37^{\circ} \mathrm{C}$. Morfologi koloni B. glumae yang tumbuh pada media agar LB atau King's B berwarna putih kusam hingga krem, berbentuk bulat dengan permukaan cembung dan mengkilap, serta bersifat diffusible non-fluorescent (Gambar 3). Dari ciri morfologi koloni yang tumbuh pada media selektif S-PG dan media LB atau King's B, dapat terlihat perbedaan tingkat pigmen kuning yang dihasilkan (Tabel 2). Pada isolat tipe A umumnya tidak menghasilkan pigmen kuning yang difussible bila ditumbuhkan pada media LB dan King's B, sedangkan isolat tipe $\mathrm{B}$ menghasilkan pigmen kuning yang terlihat jelas. Pigmen kuning ini juga dihasilkan pada saat isolat tersebut ditumbuhkan pada media selektif S-PG.

Menurut Schaad et al. (2001), koloni B. glumae memiliki karakteristik yang khas bila ditumbuhkan pada media agar, yaitu bersifat difussible nonfluorescent. Warna koloni dengan pigmen kuning 

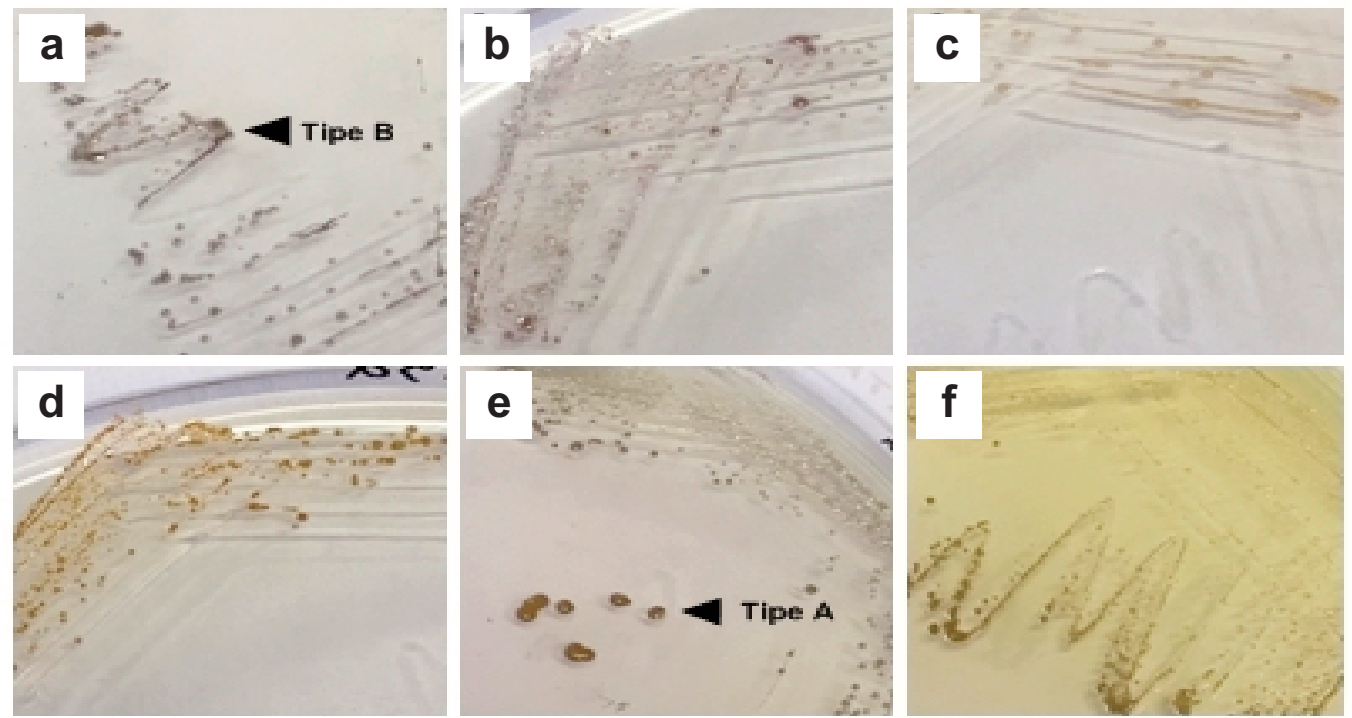

Gambar 2. Isolat hasil isolasi sampel biji padi: a) InSB.1a, b) InSB.2a, c) InSB.3a, d) InSB.5a, e) InSB.6a dan f) IRP.3; koloni Burkholderia glumae yang tumbuh pada media S-PG menghasilkan ciri morfologi yang spesifik yaitu tipe A dan B
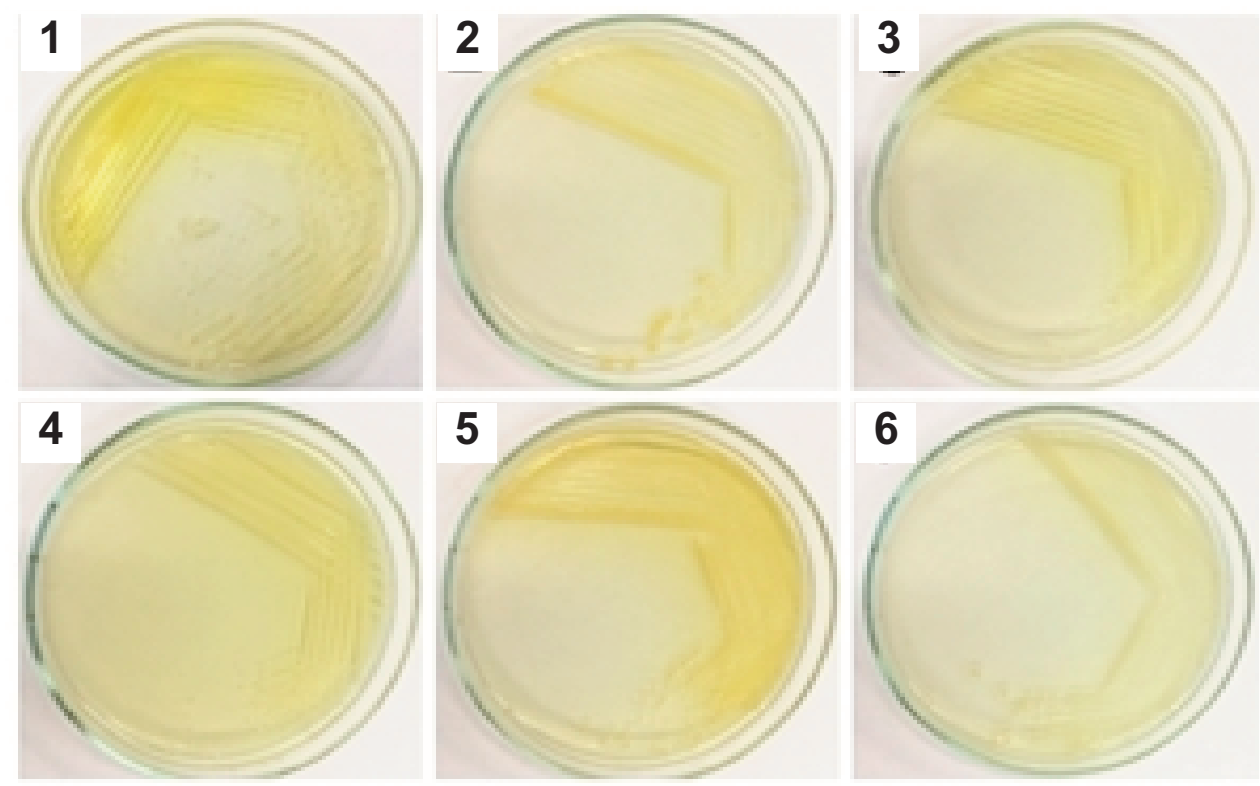

Gambar 3. Isolat Burkholderia glumae yang diisolasi dari sampel biji padi: (1) IRP.3, (2) IRP.6b, (3) InSB.3a, dan (4) InSB.6a, serta isolat B. glumae koleksi Lab. Bakteriologi Balai Besar Uji Standar Karantina Pertanian: (5) 436.10 dan (6) 479.6; isolat-isolat tersebut memiliki karakteristik morfologi koloni yaitu warna koloni yang bersifat diffusible pada media

kehijauan yang diffusible, mirip dengan koloni Pseudomonas fluorescens. Namun, pada koloni $P$. fluorescens yang ditumbuhkan pada media King's B akan menghasilkan warna berpendar (fluoresens) bila diamati di bawah sinar ultraviolet, sedangkan pada koloni $B$. glumae tidak menghasilkan pendar. Penelitian yang dilakukan oleh Nandakumar et al. (2009) terhadap 294 isolat Burkholderia memperli- hatkan sebanyak 20 isolat $B$. glumae bersifat nonpatogenik. Isolat Burkholderia yang patogenik umumnya menghasilkan pigmen kuning yang diidentifikasi sebagai senyawa toxoflavin, sedangkan isolat nonpatogen tidak menghasilkan pigmen tersebut.

Berdasarkan penelitian yang dilakukan oleh Jeong et al. (2003), pigmen kuning yang dihasilkan oleh koloni $B$. glumae merupakan toxoflavin yang 
Tabel 2. Morfologi koloni isolat bakteri hasil isolasi sampel biji padi

\begin{tabular}{|c|c|c|c|c|c|c|}
\hline \multirow[b]{2}{*}{ Kode isolat } & \multirow{2}{*}{$\begin{array}{l}\text { Tipe koloni } \\
\text { pada } \\
\text { media S-PG }\end{array}$} & \multicolumn{5}{|c|}{ Morfologi koloni pada media agar LB } \\
\hline & & Bentuk & $\begin{array}{c}\text { Tepi } \\
\text { koloni }\end{array}$ & Elevasi & Warna & $\begin{array}{c}\text { Diffusible } \\
\text { pigment }\end{array}$ \\
\hline ChgCM.1 & A & Bulat & halus & cembung & putih pucat & - \\
\hline ChgCM.2 & A & Bulat & halus & cembung & kuning pucat & - \\
\hline ChgCM.3 & A & Bulat & halus & cembung & putih pucat & - \\
\hline ChgCM.4 & A & Bulat & halus & cembung & putih pucat & $\checkmark$ \\
\hline ChgCM.5 & A & Bulat & halus & cembung & putih pucat & - \\
\hline ChgCP.2 & A & Bulat & halus & cembung & putih pucat & - \\
\hline ChgCP.3 & A & Bulat & halus & cembung & krem & - \\
\hline ChgCP.4 & $\mathrm{B}$ & Bulat & halus & cembung & krem & - \\
\hline ChgCP.5 & $\mathrm{B}$ & Bulat & halus & cembung & krem & - \\
\hline ChgCP.6 & A & Bulat & halus & cembung & krem & - \\
\hline IRC.1 & A & Bulat & halus & cembung & krem & - \\
\hline IRC. 2 & $\mathrm{~B}$ & Bulat & halus & cembung & putih pucat & - \\
\hline IRC. 3 & $\mathrm{~B}$ & Bulat & halus & cembung & krem & - \\
\hline IRC.4 & $\mathrm{B}$ & Bulat & halus & cembung & putih pucat & - \\
\hline IRC. 5 & A & Bulat & halus & cembung & putih pucat & - \\
\hline MkgC. 2 & $\mathrm{~A}$ & Bulat & halus & cembung & krem & - \\
\hline MkgC. 3 & $\mathrm{~A}$ & Bulat & halus & cembung & krem & - \\
\hline MkgC.1b & $\mathrm{B}$ & Bulat & halus & cembung & kuning pucat & - \\
\hline $\mathrm{MkgC} .2 \mathrm{~b}$ & A & Bulat & halus & cembung & krem & - \\
\hline CbP.5 & $\mathrm{B}$ & Bulat & halus & cembung & putih pucat & $\checkmark$ \\
\hline ChgP.2 & $\mathrm{B}$ & Bulat & halus & cembung & krem & - \\
\hline ChgP.3 & $\mathrm{B}$ & Bulat & halus & cembung & krem & - \\
\hline ChgP.4 & $\mathrm{B}$ & Bulat & halus & cembung & krem & - \\
\hline ChgP.5 & $\mathrm{B}$ & Bulat & halus & cembung & krem & - \\
\hline ChgP.6 & $\mathrm{B}$ & Bulat & halus & cembung & krem & - \\
\hline ChgP.7 & A & Bulat & halus & cembung & krem & - \\
\hline ChgP.8 & A & Bulat & halus & cembung & krem & - \\
\hline IRP.3 & $\mathrm{A}$ & Bulat & halus & cembung & kuning pucat & $\checkmark$ \\
\hline IRP.4 & $\mathrm{B}$ & Bulat & halus & cembung & krem & - \\
\hline IRP.5 & $\mathrm{B}$ & Bulat & halus & cembung & krem & - \\
\hline IRP.6 & $\mathrm{B}$ & Bulat & halus & cembung & kuning pucat & - \\
\hline IRP. $2 \mathrm{a}$ & A & Bulat & halus & cembung & kuning pucat & - \\
\hline IRP.3a & A & Bulat & halus & cembung & krem & - \\
\hline IRP.4a & $\mathrm{B}$ & Bulat & halus & cembung & krem & - \\
\hline IRP.5a & $\mathrm{B}$ & Bulat & halus & cembung & krem & - \\
\hline IRP.6a & A & Bulat & halus & cembung & krem & - \\
\hline IRP.7a & $\mathrm{B}$ & Bulat & halus & cembung & krem & - \\
\hline IRP.8a & $\mathrm{B}$ & Bulat & halus & cembung & krem & - \\
\hline IRP.9a & $\mathrm{B}$ & Bulat & halus & cembung & krem & - \\
\hline IRP.10a & $\mathrm{B}$ & Bulat & halus & cembung & kuning pucat & - \\
\hline IRP.1b & $\mathrm{B}$ & Bulat & halus & cembung & krem & - \\
\hline IRP.2b & B & Bulat & halus & cembung & kuning pucat & - \\
\hline IRP.3b & $\mathrm{B}$ & Bulat & halus & cembung & kuning pucat & - \\
\hline IRP.4b & B & Bulat & halus & cembung & kuning pucat & - \\
\hline IRP.5b & $\mathrm{B}$ & Bulat & halus & cembung & krem & - \\
\hline IRP.6b & A & Bulat & halus & cembung & krem & - \\
\hline Pe.1 & $\mathrm{A}$ & Bulat & halus & cembung & kuning pucat & - \\
\hline Pe. 2 & $\mathrm{~B}$ & Bulat & halus & cembung & krem & - \\
\hline Pe. 3 & $\mathrm{~A}$ & Bulat & halus & cembung & krem & - \\
\hline Pe.4 & $\mathrm{A}$ & Bulat & halus & cembung & krem & - \\
\hline Pe. 5 & $\mathrm{~B}$ & Bulat & halus & cembung & krem & - \\
\hline Pe. 6 & A & Bulat & halus & cembung & krem & - \\
\hline
\end{tabular}


Tabel 2. Morfologi koloni isolat bakteri hasil isolasi sampel biji padi (lanjutan)

\begin{tabular}{|c|c|c|c|c|c|c|}
\hline \multirow[b]{2}{*}{ Kode isolat } & \multirow{2}{*}{$\begin{array}{l}\text { Tipe koloni } \\
\text { pada } \\
\text { media S-PG }\end{array}$} & \multicolumn{5}{|c|}{ Morfologi koloni pada media agar LB } \\
\hline & & Bentuk & $\begin{array}{c}\text { Tepi } \\
\text { koloni }\end{array}$ & Elevasi & Warna & $\begin{array}{c}\text { Diffusible } \\
\text { pigment }\end{array}$ \\
\hline Pe.7 & $\mathrm{B}$ & Bulat & halus & cembung & krem & - \\
\hline Pe. 8 & $\mathrm{~B}$ & Bulat & halus & cembung & krem & - \\
\hline Pe1.2 & $\mathrm{B}$ & Bulat & halus & cembung & putih pucat & $\checkmark$ \\
\hline Pe1.3 & $\mathrm{B}$ & Bulat & halus & cembung & putih pucat & - \\
\hline $\mathrm{Pe} 1.4$ & $\mathrm{~B}$ & Bulat & halus & cembung & putih pucat & $\checkmark$ \\
\hline $\operatorname{Pe} 2.1$ & $\mathrm{~B}$ & Bulat & halus & cembung & putih pucat & $\checkmark$ \\
\hline $\mathrm{Pe} 2.3$ & A & Bulat & halus & cembung & krem & $\checkmark$ \\
\hline $\mathrm{Pe} 2.4$ & A & Bulat & halus & cembung & krem & $\checkmark$ \\
\hline ChgKP.2 & A & Bulat & halus & cembung & kuning pucat & - \\
\hline ChgKp.3 & A & Bulat & halus & cembung & kuning pucat & - \\
\hline ChgKp.4 & B & Bulat & halus & cembung & krem & - \\
\hline ChgKp.5 & B & Bulat & halus & cembung & krem & - \\
\hline ChgKp.7 & B & Bulat & halus & cembung & krem & - \\
\hline CbgB.2 & B & Bulat & halus & cembung & putih pucat & - \\
\hline CbgB. 3 & A & Bulat & halus & cembung & putih pucat & - \\
\hline In4B. 3 & B & Bulat & halus & cembung & putih pucat & - \\
\hline In4B.4 & B & Bulat & halus & cembung & putih pucat & - \\
\hline In4B. $1 b$ & B & Bulat & halus & cembung & krem & - \\
\hline In 4 B. $2 b$ & B & Bulat & halus & cembung & krem & - \\
\hline In $4 B .3 b$ & B & Bulat & halus & cembung & putih pucat & - \\
\hline In $4 B .4 b$ & B & Bulat & halus & cembung & krem & - \\
\hline InSB.3 & $\mathrm{A}$ & Bulat & halus & cembung & kuning pucat & - \\
\hline InSB.4 & A & Bulat & halus & cembung & kuning pucat & - \\
\hline InSB.1a & B & Bulat & halus & cembung & kuning pucat & $\checkmark$ \\
\hline InSB.2a & B & Bulat & halus & cembung & krem & $\checkmark$ \\
\hline InSB.3a & $\mathrm{A}$ & Bulat & halus & cembung & krem & $\checkmark$ \\
\hline InSB.4a & A & Bulat & halus & cembung & krem & $\checkmark$ \\
\hline InSB.5a & A & Bulat & halus & cembung & krem & $\checkmark$ \\
\hline InSB.6a & A & Bulat & halus & cembung & krem & $\checkmark$ \\
\hline InSB. $1 b$ & $\mathrm{~A}$ & Bulat & halus & cembung & krem & - \\
\hline InSB. $2 b$ & B & Bulat & halus & cembung & kuning pucat & - \\
\hline InSB. 3b & B & Bulat & halus & cembung & krem & - \\
\hline InSB. $4 \mathrm{~b}$ & B & Bulat & halus & cembung & krem & - \\
\hline InSB. 5b & $\mathrm{A}$ & Bulat & halus & cembung & krem & - \\
\hline InSB. $6 \mathrm{~b}$ & A & Bulat & halus & cembung & krem & - \\
\hline IRB.4 & $\mathrm{A}$ & Bulat & halus & cembung & krem & - \\
\hline SBB.1b & A & Bulat & halus & cembung & krem & - \\
\hline SBB. $2 b$ & $\mathrm{~A}$ & Bulat & halus & cembung & krem & - \\
\hline SBB.3b & B & Bulat & halus & cembung & krem & - \\
\hline SBB.4b & B & Bulat & halus & cembung & kuning pucat & - \\
\hline ChgJ.1b & B & Bulat & halus & cembung & krem & - \\
\hline ChgJ.2b & B & Bulat & halus & cembung & putih pucat & - \\
\hline ChgJ.3b & B & Bulat & halus & cembung & krem & - \\
\hline ChgJ.4b & $\mathrm{A}$ & Bulat & halus & cembung & krem & - \\
\hline ChgJ.5b & B & Bulat & halus & cembung & putih pucat & - \\
\hline CH.1 & A & Bulat & halus & cembung & krem & - \\
\hline СH.2 & A & Bulat & halus & cembung & krem & - \\
\hline $\mathrm{SmCH} .1 \mathrm{~b}$ & A & Bulat & halus & cembung & krem & - \\
\hline $\mathrm{SmCH} .2 \mathrm{~b}$ & A & Bulat & halus & cembung & krem & - \\
\hline
\end{tabular}

Keterangan: Tipe $\mathrm{A}=$ bulat, cembung, dan berwarna coklat kemerahan 
berperan terhadap patogenisitas $B$. glumae dalam menginfeksi tanaman inang. Penelitian tersebut juga memperlihatkan peranan toxoflavin dalam patogenisitas yang ditunjukkan dari gejala serta tingkat keparahan penyakit yang dihasilkan. Perlakuan toxoflavin pada tanaman tomat, wijen, perila, terung dan cabai dengan konsentrasi bertingkat menghasilkan keparahan penyakit yang berbeda.

\section{Deteksi B. glumae Menggunakan Primer Berdasarkan Daerah ITS}

Dari hasil elektroforesis (Gambar 4), terdapat pita DNA dari masing-masing isolat uji yang letaknya berada di bawah pita penanda ukuran 500 bp. Hal ini sesuai dengan panjang basa produk amplifikasi primer BGF/BGR yang berukuran 400 bp. Hasil analisis PCR menunjukkan bahwa delapan sampel isolat bakteri yang diuji dapat teramplifikasi oleh primer BGF/BGR. Hal ini sesuai dengan penelitian yang dilakukan Karki et al. (2012), yang melakukan uji konfirmasi terhadap 24 isolat $B$. glumae menggunakan primer BGF/BGR. Analisis pada daerah ITS dan urutan basa 16-23S rDNA dapat digunakan untuk mengidentifikasi dan membedakan isolat $B$. glumae dari B. gladioli, karena B. gladioli juga dapat menginfeksi tanaman padi dan menghasilkan gejala yang mirip dengan gejala oleh infeksi $B$. glumae. Selain itu, beberapa laporan menyatakan bahwa $B$. gladioli juga dapat diisolasi dari tanaman padi dan menyebabkan penyakit hawar malai kompleks (Nandakumar et al., 2009).

Hasil analisis PCR ini juga menunjukkan bahwa baik isolat tipe A maupun tipe $\mathrm{B}$, dapat diamplifikasi dengan baik menggunakan primer tersebut. Adanya perbedaan pada morfologi koloni $B$. glumae yang ditumbuhkan pada media agar dapat disebabkan oleh adanya faktor fenotipik serta tingkat produksi toxoflavin yang berbeda oleh masing-masing strain (Jeong et al., 2003; Karki et al., 2012). Dari hasil analisis PCR juga diketahui bahwa B. glumae dapat dideteksi baik pada sampel biji yang memilki gejala bercak cokelat (IRP dan ChgCM), maupun sampel tanpa gejala (InSB).

Pada umumnya gejala perubahan warna (discoloration) pada biji padi dapat digunakan sebagai indikator adanya infeksi oleh bakteri patogen. Namun, B. glumae juga dapat dideteksi pada sampel yang tidak menghasilkan gejala. Fory et al. (2013) melaporkan bahwa dari 14 sampel biji yang tidak bergejala, terdapat 3 sampel yang positif terinfeksi B. glumae.

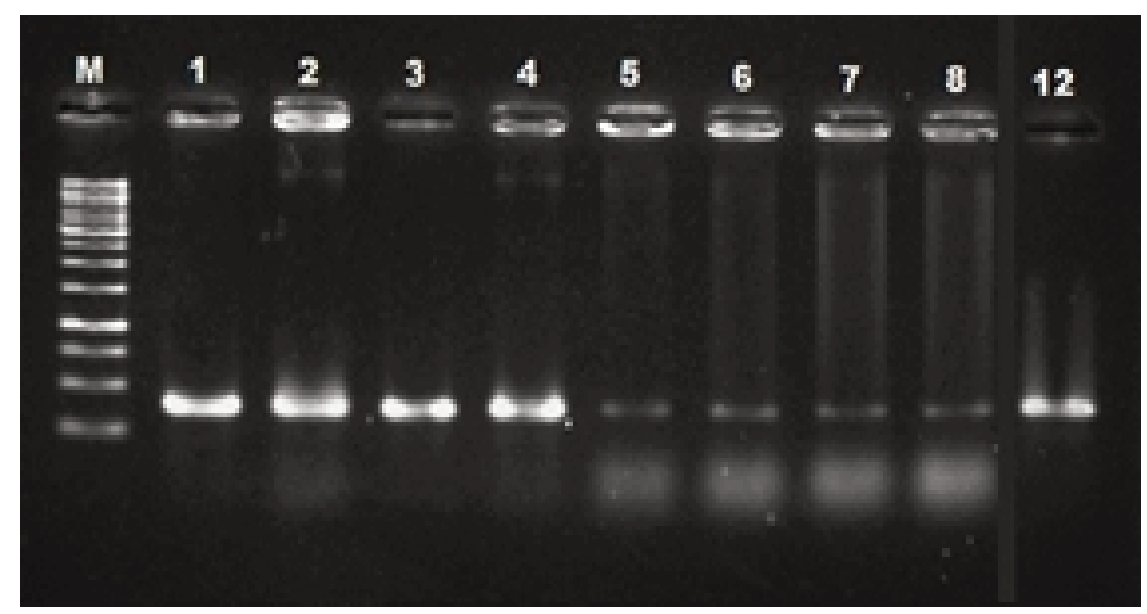

Gambar 4. Visualisasi hasil amplifikasi DNA dengan primer BGF/BGR dengan hasil produk $400 \mathrm{bp} ; \mathrm{M}=1 \mathrm{~Kb}$, $1=$ InSB.1a, $2=$ InSB.2a, 3=InSB.3a, 4=InSB.5a, 5=InSB.6a, 6=IRP.3, 7=IRP.6b, dan 8=ChgCM.4, serta $12=436.10$ (kontrol positif) 


\section{KESIMPULAN}

Isolat bakteri diperoleh dari hasil isolasi biji padi yang diperoleh dari 11 varietas padi di Jawa Barat, Jawa Tengah, Jawa Timur, dan Yogyakarta, yang memiliki karakteristik morfologi berbeda. Hasil PCR menggunakan primer BGF/BGR menunjukkan bahwa delapan isolat yang diisolasi dari varietas IR64 asal Purworejo, Ciherang asal Cirebon dan Inpari Sidenuk asal Banyuwangi terdeteksi sebagai $B$. glumae. Berdasarkan hasil penelitian, B. glumae sudah terdeteksi di pada beberapa varietas padi wilayah Jawa dan primer ITS dapat digunakan untuk mendeteksi keberadaan B. glumae baik pada biji padi yang bergejala maupun tidak bergejala.

\section{UCAPAN TERIMA KASIH}

Terima kasih saya sampaikan kepada Badan Karantina Pertanian Kementerian Pertanian yang telah mendanai penelitian. Balai Besar Uji Standar Karantina Pertanian (BBUSKP) yang telah memfasilitasi penelitian ini. Naskah ini merupakan bagian dari tesis.

\section{DAFTAR PUSTAKA}

Anonim. 2017. Luas Panen Padi Menurut Provinsi (ha), 1993-2015. https://www.bps.go.id/linkTableDinamis/view/id/864, diakses 20/8/17.

Cottyn, B., M.T. Cerez, M.F. Van Outryve, J.Barroga, J. Swings, \& T.W. Mew. 1996. Bacterial Diseases of Rice. I. Pathogenic Bacteria Associated with Sheath Rot Complex and Grain Discoloration of Rice in the Philippines. Plant Disease 80: 429-437.

Dwimartina, F., T. Arwiyanto, \& T. Joko. 2017. Potential of Endophytic and Rhizobacteria as an Effective Biocontrol for Ralstonia syzygii subsp. syzygii. Asian Journal of Plant Pathology 11: 191-198.

Fory, P.A., L. Triplett, C. Ballen, J.F. Abello, J. Duitama, M.G. Aricapa, G.A. Prado, F. Correa, J. Hamilton, J.E. Leach, J. Tohme, \& G.M. Mosquera. 2013. Comparative Analysis of Two Emerging Rice Seed Bacterial Pathogens. Phytopathology 104: 436-444.

Ismiyatuningsih, T. Joko, \& S. Hartono. 2016. Survey and Detection of Pectobacterium atrosepticum in Major Potato-Growing Areas in Central Java Province, Indonesia. Ilmu Pertanian 1: 1-6.
Jeong Y., J. Kim, S. Kim, Y. Kang, T. Nagamatsu, \& I. Hwang. 2003. Toxoflavin Produced by Burkholderia glumae Causing Rice Grain Rot is Reposible for Inducing Bacterial Wilt in Many Field Crops. Plant Disease 87: 890-895.

Joko, T., S. Subandiyah, \& S. Somowiyarjo. 2000. The Role of Extracellular Protein on the Pathogenicity of Xanthomonas campestris pv. citri. Jurnal Perlindungan Tanaman Indonesia 6: 32-38.

Joko, T., H. Hirata, \& S. Tsuyumu, 2007. A Sugar Transporter (MfsX) is also Required by Dickeya dadantii 3937 for in Planta Fitness. Journal of General Plant Patholology 73: 274-280.

Joko, T., D. Kiswanti, S. Subandiyah, \& Hanudin. 2011a. Occurence of Bacterial Soft Rot of Phalaenopsis Orchids in Yogyakarta and West Java, Indonesia, p. 255-265. In Y. Koentjoro (ed.), Proceeding of Internasional Seminar on "Natural Resources, Climate Change, and Food Security in Developing Countries", Surabaya, Indonesia, June 27-28, 2011.

Joko, T., N. Kusumandari, \& S. Hartono. 2011b. Optimasi Metode PCR untuk Deteksi Pectobacterium carotovorum Penyebab Penyakit Busuk Lunak Anggrek. Jurnal Perlindungan Tanaman Indonesia 17: 54-59.

Joko, T., M.P. Koentjoro, S. Somowiyarjo, M.S. Rohman, A. Liana, \& N. Ogawa. 2012. Response of Rhizobacterial Communities in Watermelon to Infection with Cucumber Green Mottle Mosaic Virus as Revealed by Cultivation-Dependent RISA. Archives of Phytopathology and Plant Protection 45: 1810-1818.

Joko, T., A. Subandi, N. Kusumandari, A. Wibowo, \& A. Priyatmojo. 2014. Activities of Plant Cell Wall-Degrading Enzymes by Bacterial Soft Rot of Orchid. Archives of Phytopathology and Plant Protection 47: 1239-1250.

Joko, T. 2017. Burkholderia glumae sebagai Emerging Pathogen: Status, Potensi Kerusakan, dan Strategi Pengedalian, hlm. 27-35. Dalam M. G. Pradana \& N. Mubin (ed.), Prosiding Simposium Nasional Fitopatologi, Bogor, 10 Januari 2017.

Joko, T., M. Umehara, T. Murata, H. Etoh, K. Izumori, \& S. Tsuyumu. 2018. Hyperinduction of Pectate Lyase in Dickeya chrysanthemi EC16 by PlantDerived Sugars. Journal of Plant Interactions 13: 141-150. 
Karki, H.S. , B. K. Shrestha, J. W. Han, D. E. Groth, I. K. Barphagha, M. C. Rush, R. A. Melanson, B.S. Kim, \& J. H. Ham. 2012. Diversities in Virulence, Antifungal Activity, Pigmentation and DNA Fingerprint among Strains of Burkholderia glumae. PLoS ONE 7: e45376.

Mahfut, T. Joko, \& B.S. Daryono. 2016. Molecular Characterization of Odontoglossum Ring Spot Virus (ORSV) in Java and Bali, Indonesia. Asian Journal of Plant Pathology 10: 9-14.

Nandakumar, R., A. K. M. Shahjahan, X. L. Yuan, E. R. Dickstein, D. E. Groth, C. A. Clark, R. D. Cartwright, \& M. C. Rush. 2009. Burkholderia glumae and B. gladioli Cause Bacterial Panicle Blight in Rice in the Southern United States. Plant Disease 93: 896-905.

Santoso \& A. Nasution. 2017. Pengendalian Penyakit Blas dan Penyakit Cendawan Lainnya. Balai Besar Penelitian Tanaman Padi. http://bbpadi.lit bang.pertanian.go.id/index.php/publikasi/ar tikel-ilmiah/content/item/202-pengendalianpenyakit-blas-dan-penyakit-cendawan-lainnya; diakses 10/8/17.

Schaad, N.W., W. Chun, \& J. B. Jones. 2001. Burkholderia, p. 139-150. In N.W. Schaad, J.B. Jones, \& W. Chun (eds.), Laboratory Guide for Identification of Plant Pathogenic Bacteria. $3^{\text {rd }}$ ed. American Phytopathological Society, St. Paul, Minnesota.

Suparyono, Sudir, \& Suprihanto. 2004. Pathotype Profile of Xanthomonas oryzae pv. oryzae Isolates from the Rice Ecosystem in Java. Indonesian Journal of Agricultural Science 5: 63-69.
Takeuchi, T., H. Sawada, F. Suzuki, \& I. Matsuda. 1997. Specific Detection of Burkholderia plantarii and B. glumae by PCR Using Primers Selected from the 16S-23S rDNA Spacer Regions. Annals of the Phytopathological Society of Japan 63: 455-462.

Tsushima, S., S. Wakimoto, \& S. Mogi. 1986. Medium for Detecting Pseudomonas glumae Kurita et Tabei, the Causal Bacterium of Grain Rot of Rice. Annals of the Phytopathological Society of Japan 52: 253-259.

Tsushima, S., H. Naito, \& M. Koitabashi. 1995. Change in Panicle Susceptibility Associated with Flowering Rate of Spikelets in Bacterial Grain Rot of Rice Caused by Pseudomonas glumae. Annals of the Phytopathological Society of Japan 61: 109-113.

Tsushima, S. 1996. Epidemiology of Bacterial Grain Rot of Rice Caused by Pseudomonas glumae. JARQ 30: 85-89.

Wamishe, Y. 2014. Bacterial Panicle Blight of Rice. Forum for Agricultural Risk Management in Development. http://www.agriskmanagementfo rum.org/content/bacterial-panicle-blight-rice, diakses 20/3/17.

Windari, U., T. Joko, \& S. Subandiyah. 2015. Deteksi Penyakit Bacterial Fruit Blotch pada Melon Menggunakan Elisa. Jurnal Perlindungan Tanaman Indonesia 19: 1-5.

Zhou-qi, C., Z. Bo, X. Guan-lin, L. Bin, \& H. Shi-wen. 2016. Research Status and Prospect of Burkholderia glumae, the Pathogen Causing Bacterial Panicle Blight. Rice Science 23: 111-118. 